\title{
Criteria, Indicators and Levels Future Primary School Teacher's Readiness to Collaboration with Heterogeneous Groups of Students
}

\author{
Olena Matviienko \\ Doctor of Pedagogical Sciences \\ Tetiana Tutova \\ Postgraduate student \\ Dragomanov National Pedagogical University (Ukraine,Kyiv)
}

\begin{abstract}
The article deals with the problem of future primary school teacher's readiness to collaboration with heterogeneous groups of students in the conditions of New Ukrainian School. The results of the theoretical research performed on the basis of the analysis of literary and scientific sources devoted to the study of the essence of " future primary school teacher's readiness to pedagogical interaction with heterogeneous groups of students" as a dynamic integrative personal formation, allowed to determine the following main structural components: motivational-value, informational- cognitive, person-communicative and reflexive-activity.

The authors analyzed the definitions of "criterion" and "indicator" and presented the criteria and corresponding indicators of the formation of future primary teacher's readiness to pedagogical interaction with heterogeneous groups of students, in particular motivation-value, information-cognitive, personcommunicative and reflective-activity, as well as it was characterized in detail by levels of its formation (low, medium and high).
\end{abstract}

Key words: future primary school teacher's readiness to collaboration with heterogeneous groups of students, criteria, indicators, levels.

Актуальність дослідження. На сучасному етапі розвитку педагогічної теорії та практики актуального характеру набувають питання фахової підготовки майбутніх вчителів початкової школи, компетентних та зорієнтовних на формування всебічно розвиненої особистості кожного учня, здатного до успішної співпраці з різноманіттям учнівської аудиторії, виховання в кожного учня моральнодуховних інтересів, якостей, що складають вселюдські цінності. Для ефективності професійної діяльності важливо, щоб майбутній педагог професійно діяв в ситуації невизначеності, демонстрував високий рівень толерантності та коректності особистісних та професійних відносин з всіма суб'єктами освітнього процесу в умовах Нової української школи.

Аналіз останніх досліджень $\boldsymbol{i}$ публікацій. Фундаментальні питання професійно-педагогічної підготовки освітянських кадрів і формування готовності майбутніх учителів до професійної діяльності розглядають О. Абдулліна,
А.Алексюк,
В.Бондар,
Р.Вайнола,
Ю.Галагузова, Л.Завацька,
І.Звєрєва 
Б.Гершунський,С.Гончаренко, К.Дурай-Новакова, М.Свтух, І.Зязюн, А.Капська, 3.Левчук, Л.Маєвська, О.Матвієнко, Л.Міщик, О.Міщенко, О.Карпенко, І.Ковчина, Г.Лактіонова, О.Матвієнко, В.Поліщук, В.Сластьонін, В.Щербина, С.Харченко та ін Розглянувши роботи різних авторів 3 питань готовності до професійної діяльності, слід зауважити, що єдиного підходу до трактування цього питання не має. У своїх розвідках науковці розкривають проблеми формування готовності до професійного саморозвитку (О.Пєхота), інноваційної професійної діяльності (В.Шубинський), саморегуляції педагогічної діяльності (А. Ліненко). Предметом дослідження були питання структури готовності (Н. Кузьміна); показників готовності до педагогічної діяльності (О.Балл); змістових характеристик поняття готовності (В.Моляко). У наукових дослідженнях значне місце посідає розроблення психологічної концепції готовності, яка розглядається як установка (Д.Узнадзе), психічний стан (Л.Кандибович), комплекс здібностей (Г. Балл).

Розглянувши роботи різних авторів з проблеми готовності до професійної діяльності майбутніх педагогів, піддавши аналізу структурні компоненти готовності, виконані різними вченими ми прийшли до висновку, що єдиного підходу з цього питання немає. У структурі готовності майбутніх вчителів початкових класів до педагогічної взаємодії з гетерогенними групами учнів ми виділили 4 структурних компонентів готовності майбутніх вчителів початкової школи до педагогічної взаємодії з гетерогенними групами учнів: мотиваційноціннісний, інформаційно-когнітивний, особистісно-комунікативний та рефлексивнодіяльнісний компоненти, які тісно пов'язані між собою, оскільки мають єдину мету.

Таким чином, виходячи 3 вищенаведеного, ми визначили мету та завдання статті - визначити критерії, показники та рівні готовності майбутніх учителів початкової школи до педагогічної взаємодії з гетерогенними групами учнів.

Виклад основного матеріалу дослідження. Необхідною і найважливішою передумовою визначення ефективності формування готовності студентів до педагогічної взаємодії з гетерогенними групами учнів є обгрунтування відповідних критеріїв і показників сформованості досліджуваної якості.

Аналіз психолого-педагогічних джерел свідчить про те, що проблема критеріїв та показників сформованості різноманітних складників професійно-педагогічної готовності майбутніх вчителів початкової школи висвітлюються у працях багатьох дослідників (Ю.Лук’янова, Г.Олійник, Н.Ковалевська, Л.Кідіна, Т.Швець, Н.Доценко та інші) 
Дослідники майже єдині у тлумаченні поняття «критерії», яке спирається на довідникові видання, де критерій (від грец. kriterion - засіб судження, мірило) визначається як: «мірило оцінки, думки» [5; с.307]; «ознака, на підставі якої дається оцінка якого-небудь явища, дії; ознака, взята за основу класифікації» [7; с.163].

Термін «показник» визначається як: свідчення, доказ, ознака чого-небудь; наочні дані про результати якоїсь роботи, якогось процесу; дані про досягнення чого-небудь [3]. Влучною є думка Н. Баловсяк, що показники - це кількісні та якісні характеристики сформованості кожної якості, властивості, ознаки об'єкту, котрий вивчається, тобто міра (ступінь) сформованості того чи іншого критерію [2]

3 метою ефективного визначення критеріїв готовності майбутніх вчителів початкової школи до педагогічної взаємодії з гетерогенними групами учнів доцільно встановити співвідношення понять “показник” та “критерій”. Беручи до уваги сутність “критерію”, “показник” виступає як співвідношення окремого до загального: де кожен критерій являє собою групу показників, які якісно та кількісно його характеризують. При цьому показник більш динамічний, а критерій стабільний, а кожен із визначених критеріїв та показників має свої особливості.

Виходячи 3 теоретично обгрунтованої сутності та структури готовності студентів до педагогічної взаємодії з гетерогенними групами учнів, нами виділені основні критерії ефективності цього процесу, що охоплюють виділені та науково обгрунтовані складники готовності майбутнього вчителя початкової школи до педагогічної взаємодії з гетерогенними групами учнів, а саме: мотиваційноизінісний, інформаційно-когнітивний, особистісно-комунікативний та рефлексивно-діяльнісний.

В основі обгрунтування мотиваційно-ціннісного критерію лежить твердження, що будь-яка діяльність людини викликана певними мотивами. Поняття "мотив" означає спонукання до діяльності, спонукальну причину дій, вчинків. Формування готовності майбутніх вчителів початкової школи до педагогічної взаємодії з гетерогенними групами учнів розглядається як:

сформованість особистої мотиваційної налаштованості студентів на таку діяльність у якій віддзеркалюються мотиви, потреби, інтереси особистості, бажання здобувати знання, уміння, навички та бажання долати труднощі задля успішної співпраці 3 гетерогенними групами учнів, а також бажання вдосконалюватися та саморозвиватися в професійній діяльності; 
- сформованість загальнолюдських ціннісних орієнтацій майбутніх вчителів початкової школи, що включає в ціннісне ставлення особистості майбутнього педагога до різноманіття учнів, їх унікальності та неповторності, усвідомлення важливості прийняття та розуміння їх відмінностей; володіння морально-етичним регулятором взаємовідносин особистості педагога з гетерогенними групами учнів, а саме інклюзивними цінностями, які мають бути притаманні майбутньому педагогу Нової української школи (толерантність, емпатія, любов, емоційна мобільність, відповідальність, активність, моральність та інше).

Інформаційно-когнітивний критерій передбачає:

- засвоєння системи відповідних професійно значущих знань в галузі «Педагогіки багатоманіття", які дозволяють формувати в майбутніх спеціалістів цілісне уявлення про гетерогенний аспект освіти, та активне використання знань на практиці.

- обізнаність та здатність опрацьовувати новий матеріал, самостійно здобувати знання та підвищувати рівень своєї професійної компетентності. Даний критерій відображує повноту й дієвість знань у процесі педагогічної взаємодії 3 гетерогенними групами учнів. Це знання теоретичних основ «Педагогіки багатоманіття»: знання сутності понять «гетерогенність» та «інклюзія» в освітньому процесі та їх відмінність; знання критеріїв багатоманіття та типологію гетерогенних груп учнів; знання закономірностей та принципів педагогіки багатоманіття; знання педагогіки толерантності в гетерогенному освітньому середовищі; знання педагогіки співпраці з гетерогенними групами учнів.

Особистісно-комунікативний критерій характеризується наявністю професійно важливих особистісних якостей, які впливають на результат педагогічної взаємодії з гетерогенними групами учнів, а саме толерантністю; сформованістю організаторських, комунікативних та проектувальних умінь та навичок майбутніх вчителів початкової школи будувати різновекторні толерантні взаємини з гетерогенними групами учнів та знаннями законів спілкування, норм професійної етики, технології та психології педагогічного спілкування, міжнаціонально-специфічних особливостей спілкування в умовах гетерогенного освітнього середовища.

Сутність рефлексивно-діяльнісний критерію передбачає : 
- здійснення майбутнім педагогом об'єктивного осмислення й оцінки власних дій у процесі професійного саморозвитку, що дозволяє виокремити складові успіху або виявити причини невдачі своєї діяльності;

- сформованості у студентів умінь оцінювати навчально-виховний процес в психолого-педагогічних аспектах 3 урахуванням реалізації індивідуального та диференційованого підходів; регулярно та свідомо здійснювати рефлексію власної професійної діяльності.

Результати теоретичного аналізу проблеми доводять, що сформованість готовності майбутніх вчителів початкової школи до педагогічної взаємодії представляє цілісну взаємодію всіх вище окреслених компонентів, критерії та показники сформованості яких представлено у табл.1.

Критерії та показники готовності майбутніх вчителів початкової шкли до педагогічної взаємодії з гетерогенними групами учнів.

\begin{tabular}{|c|c|}
\hline Критерії & Показники \\
\hline $\begin{array}{l}\text { Мотиваційно- } \\
\text { ціннісний }\end{array}$ & $\begin{array}{l}\text { - сформованість стійкої мотивації до прийняття та } \\
\text { розуміння гетерогенності в освітньому середовищі; } \\
\text { - позитивне налаштуванням та орієнтації особистості } \\
\text { майбутнього педагога на інклюзивні цінності та } \\
\text { толерантну співпрацю з гетерогенними групами учнів; } \\
\text { - прагнення до збагачення знань в галузі «Педагогіки } \\
\text { Багатоманіття», } \\
\text { - бажання досягати успіху та долати труднощі у } \\
\text { спілкуванні та співпраці; } \\
\text { - потреба у саморозвитку та самовдосконалення в } \\
\text { професійній діяльності. }\end{array}$ \\
\hline $\begin{array}{l}\text { Інформаційно- } \\
\text { когнітивний }\end{array}$ & $\begin{array}{l}\text { - повнота, змістовність, глибина, цілісність, системність та } \\
\text { дієвість знань майбутнього вчителя початкової школи в } \\
\text { галузі «Педагогіки Багатоманіття»: } \\
\text { - знання основ «Педагогіки Багатоманіття», критеріїв } \\
\text { багатоманіття, типології гетерогенних груп, принципи та } \\
\text { закономірності педагогіки багатоманіття; } \\
\text { - розуміння понять «гетерогенність», «гетерогенна група», }\end{array}$ \\
\hline
\end{tabular}




\begin{tabular}{|c|c|}
\hline & $\begin{array}{l}\text { «інклюзія», «особливі освітні потреби» та «толерантність»в } \\
\text { освітньому контексті; } \\
\text { - обізнаність основами полівимірного педагогічного } \\
\text { мислення; } \\
\text { - знання основ та видів комунікації та педагогічної } \\
\text { взаємодії з гетерогенними групами учнів; } \\
\text { - обізнаність основними діагностики гетерогенних груп } \\
\text { учнів та педагогічними технологіями. }\end{array}$ \\
\hline $\begin{array}{l}\text { Особистісно- } \\
\text { комунікативний }\end{array}$ & 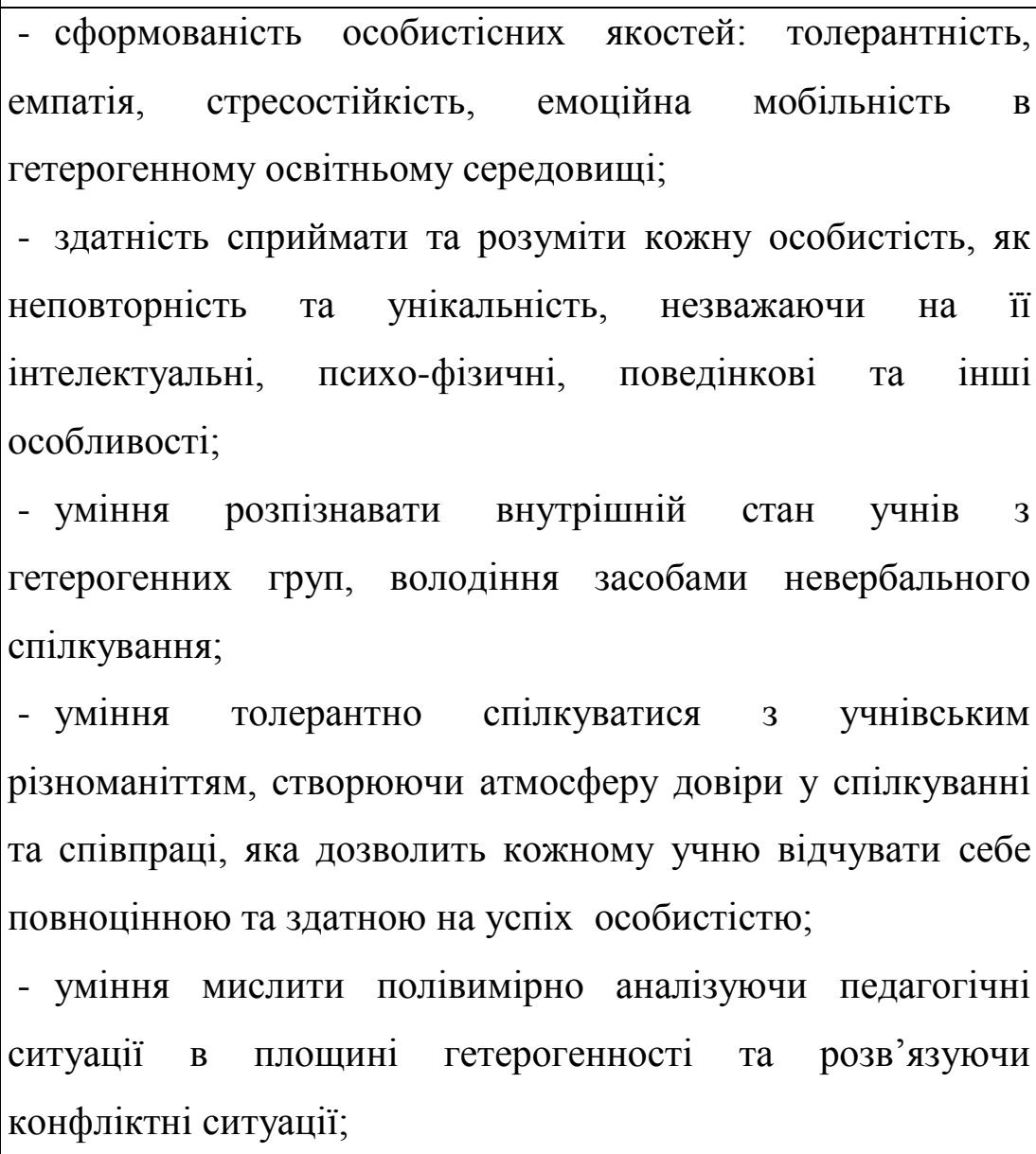 \\
\hline $\begin{array}{l}\text { Рефлексивно- } \\
\text { діяльнісний }\end{array}$ & $\begin{array}{l}\text {-уміння рефлексувати власну педагогічну діяльність та } \\
\text { особистісні якості у співпраці з гетерогенними групами } \\
\text { учнів; } \\
\text { - уміння професійно оцінювати педагогічні ситуації в } \\
\text { площині гетерогенності; проводити коригування власної } \\
\text { діяльності дотримуючись принципів педагогіки } \\
\text { багатоманіття; } \\
\text {-вміння діагностувати гетерогенні групи учнів згідно }\end{array}$ \\
\hline
\end{tabular}




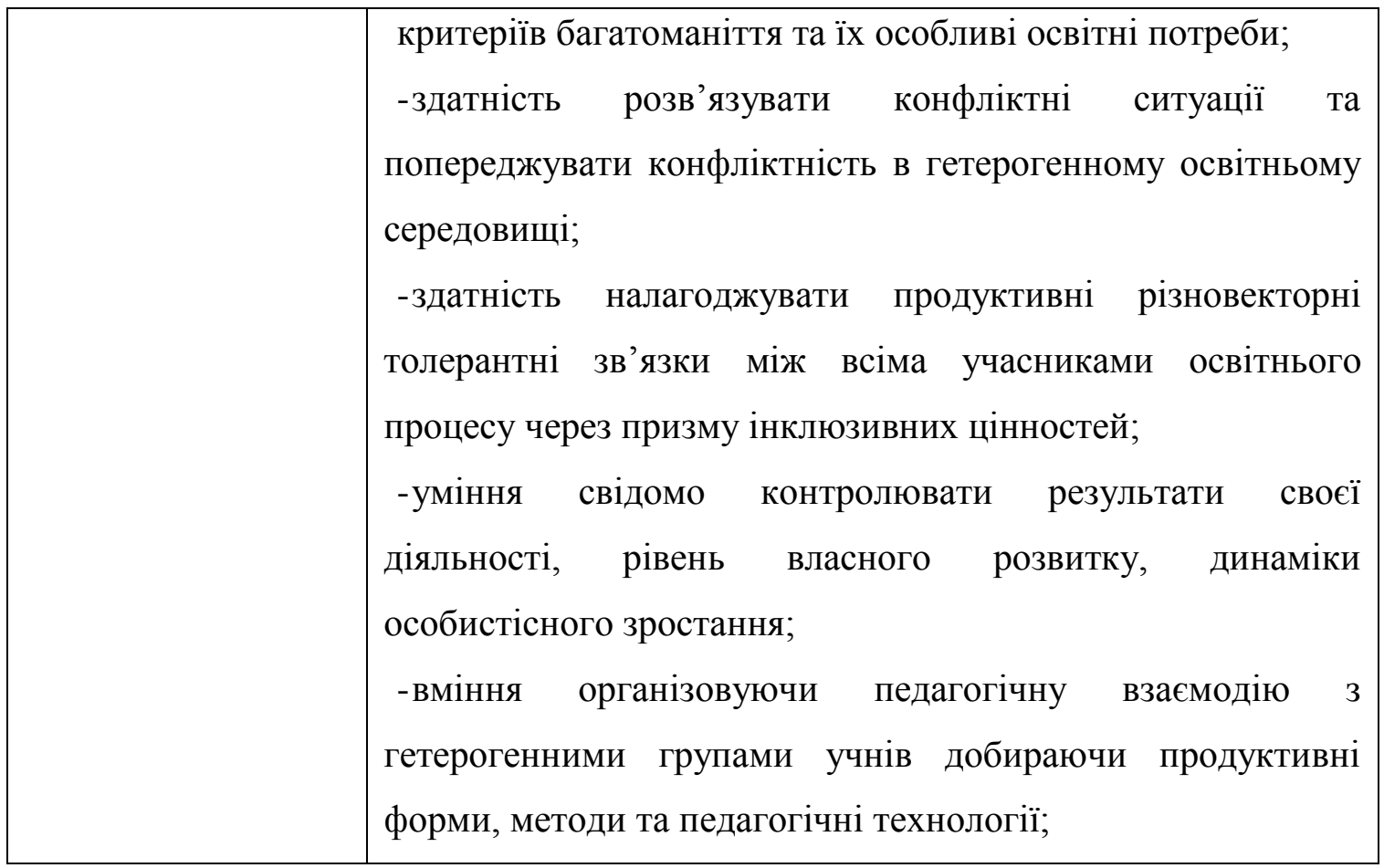

Використання зазначених критеріїв та показників готовності майбутніх вчителів початкової школи до педагогічної взаємодії з гетерогенними групами учнів дозволило визначити рівні їі сформованості, тобто послідовність змін якісних станів системи.

Наголосимо, що “рівень” розглядається як сутність розвитку певних якостей спеціаліста, що визначається набором об’єктивних чинників - критеріїв та показників, які дають змогу комплексно оцінити певне педагогічне явище та мати відповідне теоретичне і практичне обгрунтування певного педагогічного феномена.

Як засвідчив аналіз психолого-педагогічних джерел, учені для вимірювання сформованості готовності майбутніх педагогів до професійної діяльності виокремлюють трирівневу або чотирирівневу шкалу.

Якісна і кількісна характеристика визначених критеріїв і показників готовності майбутніх вчителів початкової школи до педагогічної взаємодії з гетерогенними групами учнів дає можливість виокремити три рівні прояву цього феномена високий, середній та низький.

Студентам, які перебувають на низькому рівні сформованості готовності до педагогічної взаємодії з гетерогенними групами учнів не виявляють інтересу та відсутність мотивації до педагогічної взаємодії з гетерогенними групами учнів, байдуже ставлення до результативності співпраці, відсутність бажання долати труднощі у співпраці з гетерогенними групами учнів. Студенти мають пасивний, 
епізодичний інтерес до опанування знаннями в галузі «Педагогіки Багатоманіття». Знання засвоюються формально. Майбутні педагоги уникають участі в організації та налагоджуванні продуктивних та різновекторних толерантних зв’язків 3 гетерогенними групами учнів, у студентів відсутні діагностичні та прогностичні вміння у конфліктних ситуаціях. Рефлексивно-діяльнісний компонент характеризується обмеженістю вмінь до рефлексії та професійній оцінці своєї діяльності, низькою динамікою особистісного зростання, сформованість таких професійно необхідні якостей, зокрема як толерантність, емпатійність, стресостійкість, емоційну мобільність, креативність тощо.

Студент, навчальні досягнення якого відповідають “низькому” рівню, переважно діє за підказкою, часто не може пояснити, на що спрямовані започатковані дії. Має відсутні навички організації самостійної роботи.

Студентам, у яких виявлено середній рівень сформованості готовності до педагогічної взаємодії з гетерогенними групами учнів, властива нестійка мотивації до педагогічної взаємодії з гетерогенними групами учнів,епізодичний інтерес до формування готовності до педагогічної взаємодії з гетерогенними групами учнів. Запас базових знань в галузі «Педагогіки Багатоманіття» дозволяє успішно виконувати типові завдання. Базові уміння загалом засвоєні, але студенти недостатньо вміють їх реалізовувати в співпраці з гетерогенними групами учнів на практиці.

На цьому рівні сформованості готовності до педагогічної взаємодії 3 гетерогенними групами учнів студенти вміють контролювати та керувати своїми діями у традиційних обставинах, регулярно усувають недоліки навчальної та професійної підготовленості. Динаміка особистісного зростання: сформованість таких професійно необхідні якостей, зокрема толерантність, емпатійність, стресостійкість, емоційну мобільність, креативність у таких студентів розвинені, але мають нестійку основу.

Важливою умовою для віднесення студента до групи середнього рівня навчальних досягнень $є$ наявність у нього ініціативності у досягненні професіоналізму, усвідомлення недоліків своєї підготовки та вміння критично мислити в конфліктних ситуаціях, а також прогнозувати та попереджати їх.

Для студентів, що досягли високого рівня сформованості готовності до педагогічної взаємодії з гетерогенними групами учнів, властива стійка позитивна мотивація до педагогічної взаємодії 3 гетерогенними групами учнів, стійке 
позитивне налаштування та орієнтація особистості майбутнього педагога на інклюзивні цінності, толерантну співпрацю 3 гетерогенними групами учнів дотримуючи принципів «Педагогіки Багатоманіття».

Студентам цієї групи характерні грунтовні та дієві знання в галузі «Педагогіки Багатоманіття», успішна реалізація знань, умінь та навичок у співпраці 3 гетерогенними групами учнів на практиці. У них спостерігається високий рівень володіння полівимірним професійним мисленням в площині гетерогенності, що сприяє результативності вирішення конфліктних ситуацій та запобігання конфліктності в майбутній професійній діяльності. У студентів на високому рівні сформовані навички організації самостійної роботи, що надає діяльності творчого характеру. Майбутні вчителі початкової школи компетентні діяти, оцінювати та рефлексувати свої дії у стандартних і нестандартних педагогічних ситуаціях, мають високу динаміку особистісного зростання: сформованість таких професійно необхідні якостей, зокрема толерантність, емпатійність, стресостійкість, емоційну мобільність, тощо. У співпраці в умовах гетерогенності учнівської аудиторії та конфліктних ситуаціях такі студенти, як правило, емоційно стримані та мобільні, та позитивно налаштовані.

Студенти прагнуть до творчого та професійного самовдосконалення у процесі фахової підготовки, задля успішної педагогічної взаємодії з гетерогенними групами учнів.

Висновки. Аналіз психолого-педагогічної літератури засвідчує, що сформованість готовності майбутніх вчителів початкової школи до педагогічної взаємодії з гетерогенними групами учнів можна оцінювати за мотиваційноціннісним, інформаційно-когнітивним, особистісно-комкнікативним та рефлексивно-діяльнісними критеріями. Використання зазначених критеріїв дозволяє виділити три рівні сформованості готовності майбутніх вчителів початкової школи до педагогічної взаємодії з гетерогенними групами учнів (низький, середній та високий) і далі визначити стан сформованості у них цієї професійно важливої якості.

Перспективами подальшого дослідження може бути експериментальна перевірка ефективності формування готовності майбутніх вчителів початкової школи до педагогічної взаємодії з гетерогенними групами учнів із застосуванням виділених критеріїв і показників досліджуваної якості. 


\section{References}

1. Bagrie $\mathrm{V}$. The process of formation and improvement of professional skills as a basis for professional innovation activities / V. Bagry // Visnyk of Lviv University. The series is pedagogical. - L. - 2009. - Vip. 25. - Part 2. - P. 82-91

2. Bolovsiak N.V. Formation of informational competence of the future economist in the process of professional training: diss. for the sciences. Degree Candidate ped Sciences: 13.00.04 / Balovsyak Nadezhda / The Institute of Pedagogy and Psychology of Professional Education of the Academy of Pedagogical Sciences of Ukraine. - K., 2006. 334 pp.

3. New Explanatory Dictionary of the Ukrainian Language [inc. V. Yaremenko, A.Slipushko]. - K.: The kind is "Akonit", 2001. - Volume 2 of the university. The series is pedagogical. - L. - 2009. - ED. 25. - Part 2. - p. 82 -91.

4. Ozhegov S Dictionary of the Russian Language / SI Ozhegov; ed. N.Yu. Shvedova - M $\therefore$ Sov. Encyclopedia, 1973. - 846 p.

5. Pedagogy: Tutorial / VA Slastenin, I.F. Isaev, AI Mishchenko, E.N. Shiyanov Moscow: School-Press, 1998. - 512 p.

6. Professional education: Dictionary: Teaching. manual / layout. S.U. Goncharenko and others; By Ed. N.Nobody - K .: High school, 2000.- p149.

\section{Translation of the Title, Abstract and References to the Author's Language}

\section{УДК 378.011.3-051:373.3}

Матвіснко Олена, Тутова Тетяна. Критерії, показники та рівні готовності майбутніх вчителів початкової школи до педагогічної взаємодії 3

\section{гетерогенними групами учнів.}

У статті розглядається проблема готовності майбутніх вчителів початкової школи до педагогічної взаємодії з гетерогенними групами учнів до педагогічної взаємодії в умовах Нової української школи. Результати теоретичного дослідження, виконаного на підставі аналізу літературно-наукових джерел, присвячених вивченню суті «готовності майбутніх вчителів початкової школи до педагогічної взаємодії 3 гетерогенними групами учнів» як динамічного інтегративного особистісного утворення, дозволили виокремити такі iї основні структурні компоненти: мотиваційно-ціннісний, інформаційно-когнітивний, особистіснокомунікативний та рефлексивно-діяльнісний.

Авторами здійснено аналіз дефініцій «критерій» та «показник» та представлено критерії та відповідні показники сформованості готовності майбутніх вчителів початкової школи до педагогічної взаємодії з гетерогенними групами учнів зокрема мотиваційно-цінністний, інформаційно-когнітивний, особистісно-комунікативний та 
рефлексійно-діяльнісний, а також детально охарактеризовано рівні її сформованості (низький, середній та високий).

Ключові слова: готовність майбутніх вчителів початкової школи до педагогічної взаємодї̈ з гетерогенними групами учнів, критерії, показники та рівні готовності.

\section{Jimepamypa}

1. Багрій В. Процес формування та удосконалення професійних умінь як основа для професійної інноваційної діяльності / В. Багрій // Вісник Львівського університету. Серія педагогічна. - Л. - 2009. - Вип. 25. - Ч. 2. - С. 82-91.

2. Баловсяк Н. В. Формування інформаційної компетентності майбутнього економіста в процесі професійної підготовки: дис. на здобуття наук. ступеня канд. пед. наук: 13.00.04 / Баловсяк Надія Василівна / Інститут педагогіки і психології професійної освіти АПН України. - К., 2006. - 334 с.

3. Новий тлумачний словник української мови [укл. В. В. Яременко, О. М. Сліпушко]. - К.: Вид -во «Аконіт», 2001. - Том 2 Ж -О університету. Серія педагогічна. - Л. - 2009. - Вип. 25. - Ч. 2. - С. $82-91$.

4. Ожегов С.И. Словарь русского языка / С.И. Ожегов; под ред. Н.Ю. Шведова. - М.: Сов. Энциклопедия, 1973. - 846 с

5. Педагогика: Учебное пособие / В.А. Сластенин, И.Ф. Исаев, А.И. Мищенко, Е.Н. Шиянов. - М.: Школа-Пресс, 1998. - 512 с.

6. Професійна освіта: Словник: Навч. посібник / Уклад. С.У. Гончаренко та ін.; За ред Н.Г. Ничкало. - К.: Вища школа, 2000. -С.149. 